\title{
ARTIGO
}

\section{O GÊNERO MEME PRODUZIDO COMO NARRATIVA MULTISSEMIÓTICA A PARTIR DA TRIANGULAÇÃO ENTRE DIFERENTES GÊNEROS DO DISCURSO}

\author{
Josimar Gonçalves Ribeiro \\ Centro Federal de Educação Tecnológica de Minas Gerais - CEFET, Brasil \\ josimarrp2018@gmail.com \\ Vicente Aguimar Parreiras \\ Centro Federal de Educação Tecnológica de Minas Gerais - CEFET, Brasil \\ vicentearchives@gmail.com
}

DOI: https://doi.org/10.26512/caleidoscopio.v4i1.30110

Recebido em: 23/03/2020

Aceito em: 26/06/2020

Publicado em dezembro de 2020

\begin{abstract}
RESUMO: Este trabalho apresenta um projeto piloto que expõe uma prática pedagógica com a intenção de propor uma nova forma de pensar a leitura depois da intermediação da tecnologia. Ele tem por objetivo analisar o sentido da leitura extraído da produção de uma narrativa multissemiótica proveniente da leitura do clássico literário Moby Dyck de Herman Melville. 0 público alvo são alunos do 1o ano do Ensino Médio Técnico do Instituto Federal do Sudeste de Minas Gerais Campus Rio Pomba ${ }^{2}$. 0 estudo utilizou a tradução intersemiótica como recurso didático técnico para a formação leitora. A utilização da representação imagética justificou - se por oportunizar a produção de novas linguagens mediada pela máquina. A prática analisou o clássico literário Moby Dyck de Herman Melville associados em diferentes gêneros e formato: resumo, imagem e meme. Na análise dos dados foram usadas as conceituações sobre Tradução Intersemiótica conforme Plaza (2003); a teoria do Gênero Discursivo consoante Bakhtin (1997 [1929]) e o conceito da Pedagogia de Multiletramentos segundo o Grupo de Nova Londres (1996). O resultado exibiu as múltiplas formas em linguagem em prol da formação leitora. A conclusão se fundamentou conforme Plaza (2003, p. 210) no seguinte excerto: "[...] julgamos possível ser pensada a tradução também como forma de iluminar a prática."
\end{abstract}

Palavras-chave: Gênero Meme, Narrativa Multissemiótica, Gênero do Discurso, Tradução Intersemiótica, Formação do Leitor.

\footnotetext{
${ }^{2}$ Foi respeitado o nome da instituição, visto que a investigadora possui autorização para isto.
} 


\section{THE MEME GENDER PRODUCED AS MULTISEMIOTIC NARRATIVE FROM TRIANGULATION BETWEEN DIFERENTS DISCOURSE GENDERS}

ABSTRACT: This article presents a pilot project that it proposes a pedagogical strategy to develop a new way to think the reading after the technology. It has for goal to analysis the meaning of reading takes the production of a multisemiotic narrative from the reading of literate classic Moby Dick by Herman Melville. The public is students of the $1^{\text {st }}$ year of the Integrated Technical High School course of the Federal Institute of the Southeast of Minas Gerais, Rio Pomba Campus. The study uses intersemiotic translate as teaching technical resource for formation of the reader. The use of image representation justified to produce the new language mediate by machine. The practice analyzed the literary book Moby Dyck by Herman Melville associated in diferents genders and form: abstract, images; meme. In the data analysis were used the concepts of Intersemiotic Translate according Plaza (2003); the concept of Discourse Gender according Bakhtin (1997 [1929]) and the concept of A Pedagogy of Multiliteracies according New London Group (1996). The conclusion demonstrates the language as the multi way to reading training, according Plaza (2003): "[...] we judge the translate as possible way to illuminate the practice."3

Keywords: Meme Gender, Multisemiotic Narrative, Discourse Gender, Iintersemiotic Translate, Formation of the Reader.

\section{Introdução}

O que é a leitura? Pergunta antiga que sustenta mistérios indecifráveis até hoje. Houve ao longo dos anos um progresso diversificado nas técnicas para elaboração de textos e estratégias de leitura. As diversificações foram oriundas de investigações, aplicações, experiências e conceituações que receberam um impacto gigantesco da tecnologia.

A transformação tecnológica ampliou pesquisas, sentidos, compreensões, rompeu limites em todas as áreas que circundam o ser humano. Ela possibilitou divisões e/ou junções de diferentes campos do saber, ou seja, desafiou e desafia o homem a se reinventar e estar sempre em busca de novas significações.

0 texto é suporte condutor de imagens, sons, formas e organizações que vêm desafiando o homem na construção do pensamento. A linguagem é reconstruída por múltiplos formatos. A imagem com a era computacional reformulou outros significados e reafirmou a sua importância ao lado da escrita. Por causa dessas

\footnotetext{
3 Tradução para língua inglesa feita pela autora do trabalho.
} 
transformações tecnológicas, a abstração iniciou uma sustentação dicotômica em destruir e reconstruir. A informação recebeu e recebe contínuas atualizações e com isso, ocorre a geração de outros meios de interação e armazenamento de dados. 0 imaginário impulsionou "possibilidades insuspeitadas ao utilizarem de forma intensiva ou transgressiva os recursos enunciadores colocados à sua disposição pelas máquinas" (MACHAD0, 1993, p. 13).

Assim, a proposta deste trabalho é mostrar a desconstrução e reconstrução de uma obra clássica em gêneros e formato diferenciados. A execução possibilitou a inserção do fazer tradutório com o fim de veicular diversas linguagens, transitar em diferentes épocas e reestruturar uma versão semiótica da narrativa a fim de mostrar as múltiplas performances da linguagem. Isso foi pensado para que o discente tenha a chance de construir seu próprio conhecimento e aprendizagem.

De posse dessa ação, a intenção se define em propor outra forma de pensar a leitura após a intermediação da tecnologia. 0 objetivo é analisar o sentido da leitura extraída da produção de uma narrativa multissemiótica proveniente da leitura do clássico literário Moby Dick de Herman Melville, sustentada pela triangulação entre diferentes gêneros e formato: resumo, imagem e meme. Subordinado a esse pensamento, questiona-se: Quais sentidos podem ser extraídos da narrativa multissemiótica proveniente da triangulação entre diferentes gêneros discursivos advindos de um clássico literário?

A meta é a ressignificação da leitura por meio das novas problemáticas criadas pela tecnologia, e assim reconstruir outros conceitos. Recuperar a história utilizando a tradução como experiência para transformar o presente, alterar os modos de recepção a fim de “... modifica[r] a nossa percepção dessa mesma informação, provocando tradução e contaminação" (PLAZA, 2003, p. 13). Esse processo permite fomentar o diálogo "intervisual" e "intertextual" (ibid, p. 13) em múltiplas linguagens. Promover a interpretação de signos verbais e não-verbais fixados em diferentes suportes dentro de um constante deslocamento ou alocação de informação.

A tradução, realizada no processo que será descrito, se insere na concepção intersemiótica que "consiste na interpretação dos signos verbais por meio de sistemas de signos não verbais" (PLAZA, 2003, p. xi). A ação de tradução intersemiótica indica a "plasticidade da teoria semiótica que permite e exige esses trânsitos do teórico ao prático," e vice e versa (ibid, p. 210). A busca é de aflorar 
outra verdade, subverter a ordem sucessiva dos fatos para gerar outro encantamento ao leitor e assim capturar a atenção.

0 artigo se compõe nas seguintes seções: na primeira, faz-se a conceituação dos teóricos que são os pilares do estudo; depois, serão analisadas as imagens produzidas da leitura do clássico; posteriormente, demonstra-se a discussão dos resultados e, por fim, as considerações finais.

\section{Letramento multissemiótico}

Após o surgimento da máquina, as concepções e invenções sofreram bruscas transformações. A tecnologia expandiu o imaginário humano e ressignificou ações e profissões. Machado (1993) corrobora esse pensamento ao afirmar que:

\footnotetext{
0 artista da era das máquinas é, como o homem de ciência, um inventor de formas e procedimentos; ele recoloca permanentemente em causa as formas fixas, as finalidades programadas, [...] para que o padrão esteja sempre em questionamento e as finalidades sob suspeita (MACHADO, 1993, p. 15).
}

Um ponto relevante nesse progresso coube às máquinas semióticas que possuem como função a representação e a mediação entre o saber e o mundo. A tarefa delas é a materialização do pensamento, pois em "toda invenção técnica - e sobretudo quando se trata da invenção de máquinas semióticas - há sempre a emergência de uma dimensão imaginária" (MACHADO, 1993, p. 35). 0 impacto das novas tecnologias, como a Web $2.0^{4}$ entre outros, redesenharam os comportamentos dos indivíduos resultando na emergência de alterações de atitudes. A contemporaneidade exigiu revisão no sentido do letramento multimodal devido à diversidade de linguagens, mídia e variadas tecnológicas surgidas a partir desse período.

Uma dessas linguagens que se reformulou foi a visual. Ela é condutora de articulações consolidadas ou provisórias, atravessadas pela história, pelo espaço, tempo entre outros fatores. Para Warburg, historiador alemão, quando se está

\footnotetext{
${ }^{4}$ Geração de ferramentas ligadas à comunicação, compartilhamento e colaboração. Nela, os usuários são produtores e receptores de informação, ou seja, surge a cultura partilhada.
} 
perante uma imagem, paralisamos como se estivéssemos "diante de um templo complexo" (DIDI-HUBERMAN, 2013, p. 34). Ela carrega muito conhecimento e múltiplos sentidos.

Ciente desse panorama, o Grupo de Nova Londres (GNL) em 1996, propõe uma Pedagogia dos Multiletramentos que consiste em:

\begin{abstract}
apontar, já de saída, por meio do prefixo "multi” para dois tipos de "múltiplos" que as práticas de letramento contemporâneo envolvem: por um lado, a multiplicidade de linguagens, semioses e mídias envolvidas na criação de significação para os textos multimodais contemporâneos e, por outro lado, a pluralidade e a diversidade cultural trazidas pelos autores/leitores contemporâneos a essa criação de significação (ROJO, 2013, p. 14).
\end{abstract}

Portanto, os textos pertencentes à era "multi" se caracterizam como interativos, colaborativos, híbridos, entre outros aspectos. Além da capacidade de serem fragmentados e transgressores aos relacionamentos de poder, espaço, pensamentos e modalidades de textos (não verbais e verbais).

O funcionamento desses novos textos se vincula diretamente com as ações humanas, visto que a relação autor/receptor ganha outros formatos. Eles passam a povoar novos espaços, oferecer outras ferramentas, a adquirirem características colaborativas ultrapassando a concepção geográfica, a faixa etária, níveis de escolaridade entre outros limites que se tornaram tênues.

A proposta do GNL (1996), diante dessas mudanças, é formar designers de significados aptos para a produção, compreensão e reconstrução dos sentidos das diversas linguagens existentes. Para esse feito, é necessário analisar três dimensões: a diversidade produtiva que se relaciona ao mundo laboral, o pluralismo cívico, ou seja, os direitos e deveres do cidadão e as identidades multifacetadas, esfera privada.

Inserido nessa concepção, há dois pontos importantes para atentar-se na Pedagogia dos Multiletramentos que são o conteúdo (the content, "what") e a forma (The form, "how") (GNL, 1996, p. 65). 0 primeiro item, refere-se ao que se deve aprender e o segundo, a forma de apropriação desse ensino.

0 foco central dessa proposta de multiletramento é a ciência do design nos âmbitos pedagógico, de diferentes componentes curriculares, de motivação nas 
salas de aula e de diversas performances de aprendizagem. A intenção desse design é de potencializar a inteligência criativa com o constante redesenho das atividades que englobam ajuste e reflexão da própria prática.

A ação de letrar envolve “a multiplicidade de linguagens” (ROJO, 2013, p. 14) que ocorre via gêneros discursivos. Portanto, a próxima seção tratará da concepção do gênero do discurso segundo os estudos de Bakhtin (1997 [1929]).

\section{Gêneros discursivos}

Na Grécia Antiga, Aristóteles dedicou-se aos estudos da língua e propagou a noção do termo gênero com o sentido de agrupamento. A partir daí, já havia a concepção de um conjunto fundamentado em critérios de semelhança.

Após esse período, o assunto é retomado pelo Círculo composto por Mikhail Bakhtin, Valentin Volochinov e Pavel Medvédev entre outros. Para eles, gênero do discurso define-se como: "Cada esfera de utilização da língua elabora seus tipos relativamente estáveis de enunciados, sendo isso que denominamos gêneros do discurso" (BAKHTIN, 1997 [1952-1953, 1979], p. 279). Esse conceito se baseia na linguagem como instrumento principal para a realização do diálogo.

Ao aprender a língua, em meio a uma "prática social de interlocução" (BAKHTIN, 1988, p. 9), o cidadão durante a comunicação troca informações. Conforme assevera esse autor: "o discurso, ou seja, a língua em sua integridade concreta e viva e não a língua como objeto específico da Linguística, obtido por meio de uma abstração absolutamente legítima e necessária de alguns aspectos da vida concreta do discurso" (idem, 1997 [1929, p. 181). Portanto, a língua e discurso se associam simultaneamente aos seus agentes, ações, esferas sociais e a ideologia. Esse fator culmina na mutação do perfil do indivíduo, pois ele adquire um papel dialógico mediante à inserção sociointeracional.

A interação se torna o espaço de construção de enunciados (re)significados pelos interlocutores em meio ao ato de perguntar/responder; receber/compreender emissões sustentadas ideologicamente. Isso significa que o conhecimento e vivência na língua acontecem por meio de "enunciações concretas [enunciados concretos] que nós mesmos ouvimos e nós mesmos reproduzimos na comunicação discursiva viva com as pessoas que nos rodeiam"(idem, 2003a [1952- 
1953], p. 282-283). Esse processo se pauta em uma comunicação profunda entre duas vias a exterior e a interior. Assim, os gêneros do discurso estão inseridos na linguagem como princípio dialógico, e o enunciado se torna a unidade principal da comunicação discursiva.

Os gêneros discursivos estão vinculados às dimensões e as esferas comunicativas. As primeiras se subdividem em três: tema (conteúdo, local onde perpassa a comunicação de cunho ideológico); forma composicional (estrutura); estilo (marcas linguísticas) ${ }^{5}$. As últimas, referem-se: “[...] em dois grandes estratos: as esferas do cotidiano (familiares, íntimas, comunitárias etc), [...] e as esferas dos sistemas ideológicos constituídos (da moral social, da ciência, da arte, da religião, da política, da imprensa etc)" (ROJO, 2005, p. 197).

Diante desses pilares que sustentam a conceituação dos gêneros do discurso, verifica-se como as esferas e os meios comunicativos alteram o posicionamento do falante. Essas mudanças foram responsáveis pelas transformações que os gêneros discursivos sofreram. 0 gênero resumo por exemplo, é um conjunto que se molda conforme a esfera à que se vincula. Ele pode habitar cadernos de estudantes que se preparam para fazer uma avaliação, como também pode ser uma exigência acadêmica para aceitação de exposição de comunicação em um congresso. Este "texto que explicita de forma clara uma compreensão global do texto lido" (RIBEIR0, 2006, p. 76) é bem utilizado para diferentes fins particulares ou acadêmicos.

Outro ponto que moveu a mutação genérica foi a tecnologia, pois posteriormente ao seu advento, alterações e surgimentos sucederam. 0 gênero meme é um exemplo dessa evolução guiada pela tecnologia. 0 termo meme surge na obra 0 Gene Egoísta do biólogo Richards Dawkins publicado em 1976. Esse autor observa a multiplicação dos genes como " tipo de entidade [...] que sobrevive, ou não sobrevive, em consequência da seleção natural" (DAWKINS, 2007, p. 9).

Para o biólogo britânico, após os genes, surge um novo replicador em nosso planeta. Ele está diretamente relacionado com a cultura humana, que é o alimento dessa forma de linguagem. Como o cientista assevera:

0 novo caldo é o caldo da cultura humana. Precisamos de um nome para o novo replicador, um nome que transmita a ideia de uma unidade de transmissão cultural, ou uma unidade de imitação. " Mimeme" provém de uma raiz grega adequada, mas eu procuro uma palavra mais curta que soe

\footnotetext{
${ }^{5}$ Rojo (2005, p. 196)
} 
mais ou menos como "gene". Espero que meus amigos classicistas me perdoem se abreviar mimeme para meme. Se isso servir de consolo, podemos pensar, alternativamente, que a palavra "meme" guarda relação com "memória", ou com a palavra francesa même. Devemos pronunciá-la de forma a rimar com "creme" (DAWKINS, 2007, p. 330).

O biólogo comenta que os memes podem obter diferentes configurações como: "melodias, ideias, slogans" (ibid, p. 330) entre outros elementos que se espalham " no pool de memes saltando de cérebro para cérebro através de um processo que, num sentido amplo, pode ser chamado de imitação" (DAWKINS, 2007, p. 330). Essa ação em conjunto ressaltada por uma ou outra característica de propagação, também pode ser verificada na internet, visto que a tecnologia impulsionou a multiplicação incalculável desse fenômeno.

Para compreender a execução do redesenho da história de Moby Dick traduzida para uma narrativa mulissemiótica será crucial visitar a teoria da tradução intersemiótica segundo Plaza (2003). Portanto, na próxima seção serão conhecidos os conceitos e características desse estudo.

\section{Tradução intersemiótica}

A tradução é uma operação que exige o manuseio de múltiplas linguagens interligadas entre passado, presente e futuro. 0 processo dialógico usa a recuperação histórica (sincrônica e diacrônica) para projetar a releitura do passado para futuro com novos olhos. A ação de traduzir significa, então, reorganizar a história subvertendo a ordem da sucessão entre o passado e presente em novas configurações.

Para Plaza (2003), a tradução fundamentada por Jakobson se subdivide em interlingual, intralingual e intersemiótica. Essa última, “consiste na interpretação dos signos verbais por meio de sistemas de signos não verbais, ou de um sistema de signos para outro" (PLAZA, 2003, p. xi).

0 ato de pensar que é comum a todo ser humano se torna concretizado por meio de signos. Eles são os únicos elementos capazes de transitar entre o mundo interior e exterior e se traduzirem em diversos tipos de linguagem. Portanto, ele medeia o pensamento e a realidade, com o caráter representacional, visto que ele nunca será um objeto. 
A tradução intersemiótica revela os pensamentos em signos. De acordo com os estudos de Peirce (2005), teórico que sustenta a concepção semiótica utilizada por Plaza (2003), os signos mantêm uma relação tríade com seu objeto e interpretante. Isso significa que o foco principal dos signos para a tradução é o seu vínculo com o objeto, visto que a característica primordial é o poder de representação. Em outras palavras: “o pensamento, que já é signo, tem de ser traduzido numa expressão concreta e material de linguagem que permita a interação comunicativa" (PLAZA, 2003, p. 18-19). Desse modo, a concretização de todo esse processo de comunicação é exteriorizado pela linguagem.

Além da substituição de um signo por outro que acontece na tradução, há outras operações inseridas nesse ato como a leitura, a crítica e a análise. A leitura é realizada conforme o interesse e sensibilidade do tradutor. A atividade ocorre de forma dialógica entre a produção e o original. Ela se realiza em três níveis: o primeiro (o signo provoca um efeito de qualidade de sentimento), o segundo (a forma como recebe o original, a produção da experiência oriunda do real) e o terceiro (o desenvolvimento da cognição, aprendizado alcançado).

A análise e a síntese são estágios de compreensão do original, localização do processo de associações. A partir dessa etapa surgirá o poder de criação. Isso representa ser capaz de expor qualidades e singularidades ao ponto de transparecer a crítica, ou seja, uma nova forma, a invenção. Portanto, a tradução intersemiótica está diretamente ligada à sensibilidade de criação do tradutor.

Após a inserção nos conceitos da tradução intersemiótica, exibir-se-ão as observações e análises da atividade produzida pelos alunos. Abaixo, será descrita a transcriação de uma obra literária ao gênero meme com a meta de recontar a história em forma de narrativa multissemiótica.

\section{Análise}

A ideia de transcriação surgiu da proposta de produzir um trabalho que apresentasse a linguagem em outros formatos. Assim, buscou-se aliar a leitura do clássico literário Moby Dyck de Herman Melville recomendado para alunos do 1ํㅡ ano do Ensino Médio, visto que nesse período há a indicação de leituras com a 
temática sobre viagem marítima. A sugestão era aproveitar o encantamento provocado pela máquina para motivar a formação leitora.

O trabalho desenvolvido justificou-se por oportunizar a produção de novas linguagens mediada pela máquina. A escolha da tradução intersemiótica se deve à exigência de uma leitura mais aprofundada da narrativa e a possibilidade de lidar com diversas formas da linguagem.

A atividade do projeto piloto foi aplicada no Ensino Médio Técnico Integrado do Instituto Federal do Sudeste de Minas Gerais Campus Rio Pomba. Os alunos participantes pertencem ao $1^{\mathrm{o}}$ ano do curso Técnico Integrado em Informática, turma composta por 43 discentes. A tarefa consistiu em traçar um diálogo entre diferentes signos e analisar as relações produzidas pela tradução intersemiótica a fim de verificar o sentido da leitura construído na triangulação dos diferentes gêneros discursivos e da modalidade imagem. Para execução do projeto piloto apresentado como uma estratégia pedagógica para formação leitora foram seguidas as seguintes etapas: primeiramente, a leitura do clássico literário Moby Dick de Herman Melville; em segundo, a elaboração do resumo; em terceiro, a pesquisa em sites em busca de uma imagem que dialogasse com a história; e por último, a transcriação dos signos do enredo em meme a fim de narrar de forma semiótica a obra.

\section{Quadro 1- Categorias de análise da Transcriação de Formas}

\begin{tabular}{|c|c|c|}
\hline \multirow{3}{*}{$\begin{array}{l}\text { NORMA: } \\
\text { Princípios normativos }\end{array}$} & \multicolumn{2}{|l|}{$\begin{array}{l}\text { LEGISSIGNOS TRANSDUCTORES: } \\
\text { Conservam a carga energética do signo original. }\end{array}$} \\
\hline & \multicolumn{2}{|c|}{$\begin{array}{l}\text { PARAMORFISMO DO LEGISSIGNO: Um objeto estético pode ser abordado e } \\
\text { construído a partir de múltiplos signos. }\end{array}$} \\
\hline & \multicolumn{2}{|c|}{$\begin{array}{l}\text { LEGISSIGNO COMO OTIMIZAÇÃO: Associa-se com a ideia de interpretabilidade do } \\
\text { signo, ou seja, o signo-leitor, sua função é reconhecer os conceitos representativos. }\end{array}$} \\
\hline \multirow{3}{*}{$\begin{array}{l}\text { Diferentes modalidades de } \\
\text { atividades internas da } \\
\text { estruturação da linguagem } \\
\text { como cores, letras, palavras, } \\
\text { gestos etc. }\end{array}$} & \multirow{3}{*}{$\begin{array}{l}\text { ATIVIDADE SÍGNICA POR CONTIGUIDADE: } \\
\text { Eixo de articulação em que um elemento cede } \\
\text { passagem a outro que é diferente dele, mas } \\
\text { ao mesmo tempo parte dele. }\end{array}$} & $\begin{array}{l}\text { TOPOLOGIA: Indica contraste e } \\
\text { sentido. }\end{array}$ \\
\hline & & \\
\hline & & $\begin{array}{l}\text { REFERÊNCIA: Indica } \\
\text { deslocamento espaço-temporal } \\
\text { do signo. }\end{array}$ \\
\hline
\end{tabular}




\begin{tabular}{|c|c|c|}
\hline & & $\begin{array}{l}\text { CONVENÇÃO: Conexões sintáticas } \\
\text { normativas. }\end{array}$ \\
\hline & \multirow{3}{*}{$\begin{array}{l}\text { ATIVIDADE SÍGNICA POR SEMELHANÇA: } \\
\text { Eixo de associações por similaridade. }\end{array}$} & $\begin{array}{l}\text { QUALIDADES: Apresentam } \\
\text { qualidades semelhantes entre as } \\
\text { partes do signo. }\end{array}$ \\
\hline & & $\begin{array}{l}\text { JUSTAPOSIÇÃO: A proximidade } \\
\text { revela uma semelhança essencial. }\end{array}$ \\
\hline & & $\begin{array}{l}\text { MEDIAÇÃO: A relação de } \\
\text { semelhança entre as partes só é } \\
\text { despertada, porque se produz na } \\
\text { mente que percebe ou interpreta } \\
\text { um terceiro termo. Ex: metáforas } \\
\text { verbais ou visuais. }\end{array}$ \\
\hline \multirow{6}{*}{$\begin{array}{c}\text { FORMA: Condições e } \\
\text { características estruturais } \\
\text { dos objetos }\end{array}$} & \multicolumn{2}{|c|}{ PERCEPÇÃO GLOBAL: Impressões que se têm das coisas e suas relações. } \\
\hline & \multicolumn{2}{|c|}{ APRESENTAÇÃO DO SENTIMENTO: Forma mais imediata do conhecimento. } \\
\hline & \multicolumn{2}{|c|}{ SINCRONIA: Modo como uma qualidade de superfície nos apresenta à consciência. } \\
\hline & \multicolumn{2}{|c|}{ SIMULTANIEDADE: Conjuntos rítmicos e sequenciais. } \\
\hline & \multicolumn{2}{|c|}{ TOTALIDADE: Séries organizadas, como um todo indivisível. } \\
\hline & SINGULARIDADE: Qualidade de cada meic & \\
\hline \multirow{3}{*}{ NÍVEL DE LEITURA } & \multicolumn{2}{|c|}{ PRIMEIRO: Presença de um mero sentimento de qualidade como sensação. } \\
\hline & \multicolumn{2}{|c|}{ SEGUNDO : A maneira pela qual cada mente recebe e reage diante do original. } \\
\hline & \multicolumn{2}{|c|}{ TERCEIRO: Consciência de um processo no qual se desenvolve a cognição. } \\
\hline
\end{tabular}


VISÃO CRÍTICO CRIATIVA: Flagrar o que há de síntese numa análise e o que há de análise numa síntese.

Fonte: Criado, pela pesquisadora, a partir de Plaza (2003).

Por ser um projeto piloto, a aplicação dele foi testada em apenas uma das turmas cuja responsabilidade estava sob a professora de Língua Portuguesa que também é a investigadora que relata esse artigo. Devido o formato deste artigo, a exemplificação aqui das atividades realizadas na proposta de formação leitora, ficarão a cargo de apenas uma demonstração.
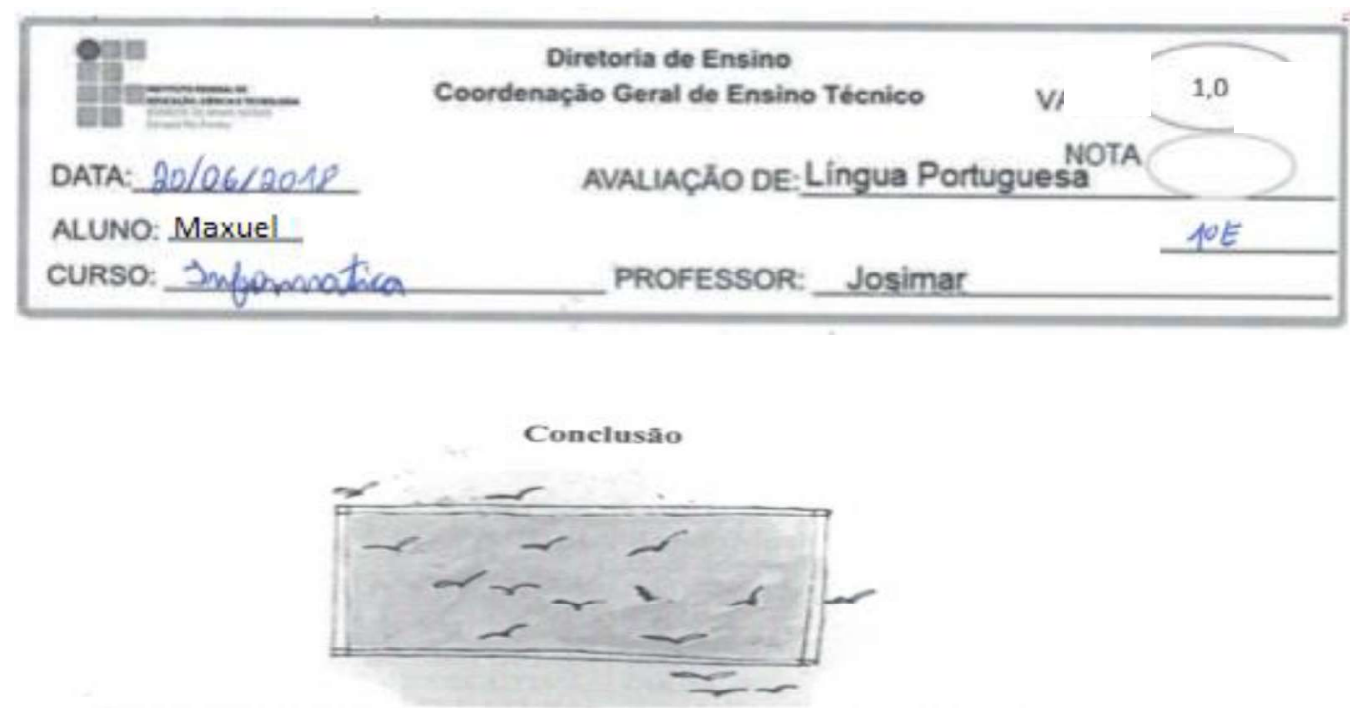

Hustraças: Nelson Cruz (Moby Dick, Herman Melville - Recontada poo Fermando Lopes, 2005?

Como foi possivel que essa história tenha chegado aqui se todos os envolvidos morreram? O fato é que alguém sobreviveu. Quis o destino que Ismael fosse poupado, Quando Moby Dick sacudiu as cordas dos arpöes, fazendo très marinhos cairem na água, foi Ismael o que nầo conseguiu voltar para o bote. Continuou a nadar para longe, e assistindo toda a cena. Estava um tanto aflastado de onde o Pequod afundou, e quase foí levado junto com o redemoinho que tinha formado, Uma caixa de salva vidas que se desprendeu do navio subiu direto a ele, que se agarrou a cla, e ficou ali boiando um dia e uma noite. No outro dia, foi recolhido por um veleiro - Raghtel - que navegava em busca dos filhos perdidos do capitão. e que agora encontraram um órfao.

Título: Conclusão do resumo Fonte: Resumo feito pelo aluno Maxuel ${ }^{6}$.

\footnotetext{
${ }^{6}$ Para preservar a identidade do aluno, foi usado nome fictício.
} 
TITULO DA OBRA: Moby Dick, Herman Melville.

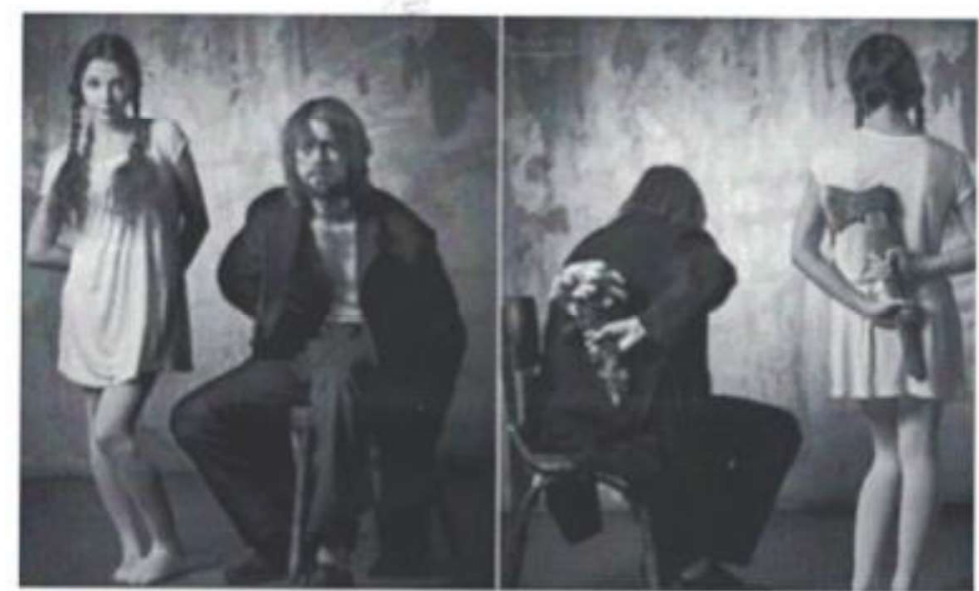

. Chtps://adventisnoemfoco, wordpress.com/201201/20 hunca-julgue-alguem-pela-aparencias

Imagem referentę̧a expressilo "nunca julgue pela aparência", na qual é retratada no livro. Nåo sabemos quem é o verdadeiro villo da história; Acab ou Moby Dick?

Título: A imagem "nunca julgue pela aparência" Fonte: Imagem pesquisada pelo aluno Maxuel.

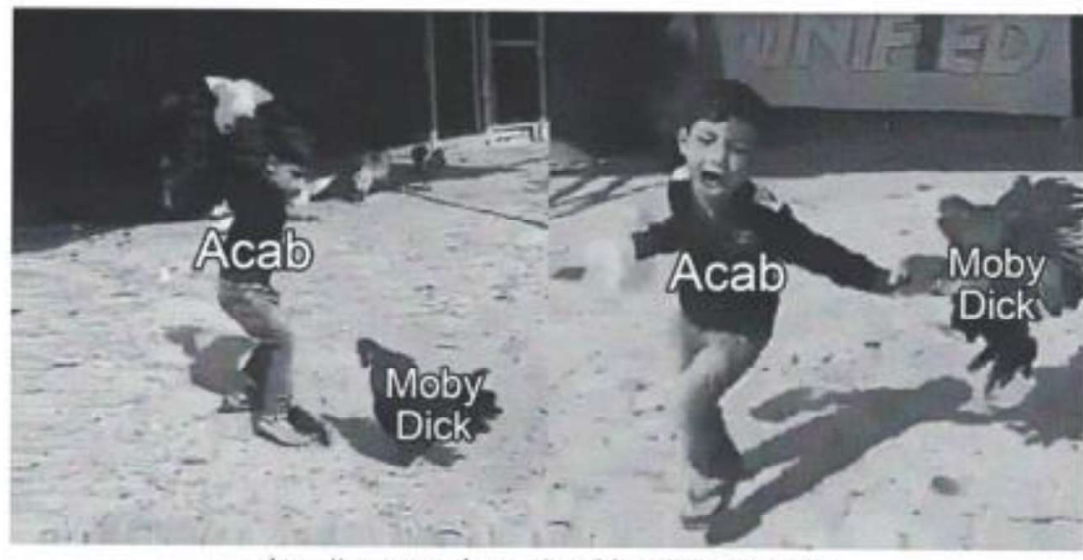

<https:/www.youtube.com/watch?v=zX7DewNetWE>

Meme que humoriza a frase "não mexa com quem está quieto", na qual Acab perde sua perna por provocar uma grande baleia que está apenas vivendo em SEU HABITAT NATURAL. E não satisfeito pela perda da perna, ele volta $\mathrm{e}$, a provoca até sua morte.

Título: Meme "não mexa com quem está quieto" Fonte: Meme criado pelo aluno Maxuel. 
Quadro 2 - Aplicação das categorias de Transcriação de Formas conforme o quadro 1

\begin{tabular}{|l|l|l|l|l|}
\hline GÊNEROS & NORMA & INTRACÓDIGO & FORMA & $\begin{array}{l}\text { NÍVEIS DE } \\
\text { LEITURA }\end{array}$ \\
\hline RESUMO & $\begin{array}{l}\text { LEGISSIGNOS } \\
\text { TRANSDUCTORES }\end{array}$ & $\begin{array}{l}\text { ATIVIDADE } \\
\text { SÍGNICA POR } \\
\text { CONTIGUIDADE } \\
\text { POR } \\
\text { CONVENÇÃO }\end{array}$ & TOTALIDADE & SEGUNDO \\
\hline IMAGEM & $\begin{array}{l}\text { LEGISSIGNO } \\
\text { COMO } \\
\text { OTIMIZAÇÃO }\end{array}$ & $\begin{array}{l}\text { ATIVIDADE } \\
\text { SÍGNICA POR } \\
\text { SEMELHANÇA } \\
\text { POR MEDIAÇÃO }\end{array}$ & $\begin{array}{l}\text { PERCEPÇÃO } \\
\text { GLOBAL }\end{array}$ & TERCEIRO \\
\hline MEME & $\begin{array}{l}\text { PARAMORFISMO } \\
\text { DO LEGISSIGNO }\end{array}$ & $\begin{array}{l}\text { ATIVIDADE } \\
\text { SÍGNICA POR } \\
\text { CONTIGUIDADE } \\
\text { POR } \\
\text { REFERÊNCIA }\end{array}$ & SINGULARIDADE & TERCEIRO \\
& & Foñ Crido, & & \\
\hline
\end{tabular}

Fonte: Criado, pela pesquisadora, a partir de Plaza (2003).

O quadro acima revela a maneira como o estudante Maxuel articulou as informações extraídas da obra Moby Dick de Herman Melville. A técnica de tradução intersemiótica mostrou que ao passo que ocorria a trancriação entre os gêneros e formato a compreensão do texto foi se esclarecendo. Também é interessante verificar como o aluno lidou melhor com imagem e o gênero meme, já que ele é um nativo digital (PRENSKY, 2001), indivíduos que nasceram imersos às transformações tecnológicas e trazem consigo aptidões naturais de manuseio com os aparelhos e ferramentas provenientes desse período. Logo, essa faixa etária à qual ele pertence revela a facilidade em trabalhar com questões tecnológicas.

A categoria Norma revela a progressão de compreensão do enredo. No resumo, Maxuel mantém a carga da narrativa em sua conclusão, já que faz a exemplificação de um personagem da história. Isso demonstra a subordinação entre seu pensamento e o enredo, e a relação de dependência. Nesse gênero, o discente não conseguiu apropriar-se do sentido da narrativa. Já na busca da imagem reflete o alcance da interpretabilidade, pois associa a história a uma expressão cotidiana 
que transmite ponderações sobre as ações dos personagens. Esse progresso de apropriação cognitiva corrobora com o pensamento:

\begin{abstract}
Na leitura online, há uma parte do processo que requer a localização de informações (buscar + avaliar para selecionar) e outra que requer compreender essa informação mais profundamente (analisar, criticar, sintetizar). Uma focaliza a busca por informação, enquanto a outra tem como foco construir um significado mais profundo (COSCARELLI, 2016, p. 76).
\end{abstract}

No gênero meme há um retorno à vinculação aos personagens. Mesmo revelando sua perspectiva a respeito do contexto da obra, esse gênero expressa a construção do meme apoiado em outros signos, mas ainda ligado às ações dos componentes da obra.

Na categoria Intracódigo, a contiguidade por convenção manifestada pelo

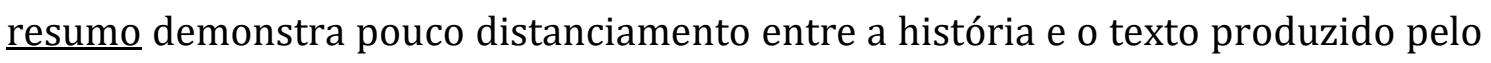
aluno. A imagem apresenta uma metáfora visual. Há a vinculação do sentido apropriado e aplicado a outros atores e em outro contexto. A sutileza da imagem e a expressão descrita mostram como esse aluno soube lidar com a navegação na internet. 0 gênero meme demonstra o deslocamento do espaço temporal ao referenciar o Ahab e a baleia. Nesse fator, houve criatividade em usar um menino e um galo, representantes de classes mais frágeis em relação ao posto de um capitão e uma baleia cachalote, animal que surpreende pelo seu tamanho e força.

$\mathrm{Na}$ categoria Forma, o gênero resumo, responsável pela síntese dos acontecimentos relevantes da história, foi produzido em condição da totalidade. Essa característica apresenta-se como séries organizadas, como um todo indivisível. Logo, ele reforça o detalhamento excessivo escrito, visto que foi redigido um texto para cada capítulo, ou seja, uma composição com 12 capítulos ${ }^{7}$, além da conclusão. Já a imagem subdividida em duas, soube muito bem expressar a percepção global de toda história. Maxuel extraiu “o conjunto de propriedades do processo perceptivo em um só, [identificou] aspectos universais na mensagem (PLAZA, 2003, p. 85). 0

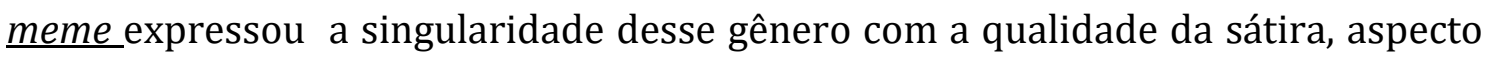
peculiar desse tipo de enunciado. A ação do garoto em bater no galo e depois correr

\footnotetext{
${ }^{7}$ Devido à amplitude do texto, somente a conclusão foi demonstrada nesse artigo.
} 
dele amedrontado e gritando mostra o humor ao se comparar com os respectivos personagens da obra representados na figura.

Na categoria Nível de Leitura, há oscilação entre o segundo e terceiro níveis. 0 resumo se enquadra no segundo nível, visto que há passagens que expressam as reações do leitor em relação ao conteúdo. 0 relacionamento nesse gênero estruturase em subordinação ao contexto original. Maxuel atinge o terceiro nível na imagem. Ele articula o sentido e apreende significados capazes de serem reformulados e representados de diferentes maneiras. 0 estudante no gênero meme também atinge o terceiro nível, ou seja, apresenta a consciência de um processo no qual se desenvolve a cognição. Há oposição de sentido dos personagens: um capitão por um garoto, uma baleia por um galo, um navio em alto mar por um galinheiro. A intenção de invasão cometido pelo ser humano ao habitat natural dos animais se transforma em humor, visto que há troca de sentido da dimensão da força dos componentes.

A visão crítico criativa expressa uma evolução satisfatória em prol da formação leitora. A síntese apresentada pelo gênero meme expressa metaforicamente a força dos personagens, ao ser exibido elementos detentores do sentido oposto ao da história. Há a sátira em trocar a baleia cachalote cujo tamanho amedronta por um galo que apesar de ser pequeno, ataca com a mesma ênfase. A invasão de um galinheiro por um garoto em contradição à luta em alto mar pelos tripulantes do navio. A análise apreendida desse gênero expressa criatividade e crítica. A descrição abaixo da figura expõe a preocupação com a ocupação geográfica feita pelo homem em atitude de confronto e desrespeito à natureza, pensamento que também pode ser extraído do clássico em questão.

\section{Discussão dos resultados}

A leitura é a chave que abre a porta do conhecimento em todos os campos. É o caminho por onde passam informações que associadas às experiências humanas se transformam em bem cultural, pessoal, social e coletivo. Assim, "a leitura é um meio para se ter acesso ao saber, aos conhecimentos formais e, sendo assim, pode[r] modificar as linhas de nosso destino escolar, profissional e social" (PETIT, 2009, p. 61). 
O conteúdo dessas leituras interfere de forma relevante na visão de mundo dos leitores. A sociedade em geral indica os cânones como a leitura certa para os jovens estudantes. Porém, há opositores que declaram todos os tipos de leitura, como boas leituras. Nesse conflito, sabe-se que:

\footnotetext{
a leitura de bons textos e a escrita, o exercício contínuo da reescrita e releitura, a comparação do que lemos e escrevemos e do que os outros lêem e escrevem nos leva a melhor ouvir, entender, falar e, portanto, exercer uma competência que em nossa sociedade letrada é arma (CHIAPPINI, 2005, p. 258).
}

Contudo, o problema não é o que ler, e sim como motivar o outro a ler. Segundo dados do PCN de Língua Portuguesa (1998): “apenas um em cada quatro jovens e adultos brasileiros consegue compreender totalmente as informações contidas em um texto e relacioná-las com outros dados" (BRASIL, 1998, p. 16).

As atividades de tradução intersemiótica foram utilizadas como recurso técnico e didático a fim de se tornarem instrumento motivador para atrair a atenção dos estudantes. Esse exercício se justificou pela barreira posta pelos discentes quando foi solicitada a leitura de alguns livros.

O primeiro obstáculo foi que poucos alunos se alegraram com a proposta de leitura. No início, somente alguns realizaram a leitura e para solucionar esse impasse, fizeram-se aulas debates em que trechos dos livros eram expostos, discutidos, analisados e anotados. Logo, depois dessas reuniões, se tornou possível a leitura da obra pela maior parte da classe. Assim, de um total de 43 alunos, apenas 10 não executaram a sugestão, tendo 33 participantes do projeto piloto.

0 ponto negativo dessa sugestão foi que mesmo sendo um projeto piloto que tinha seu peso avaliativo dentro do semestre, 10 discentes preferiram perder nota a fazer a atividade. Esse fator foi preocupante, devido à extensão da tarefa que tinha o planejamento de ser executada no primeiro semestre de 2018.

Os pontos positivos foram a busca de imagens e a criação de memes que representavam a obra. A oportunidade de inserir a internet fundamentada em solicitação escolar trouxe entusiasmo para os discentes. Desse modo: 
o caráter transductor e de interface das novas formas eletrônicas, tornase agora de uma importância ainda não avaliada na sua dimensão exata. De fato, na sociedade tecnológica, a tendência cada vez mais vai no sentido do uso de processos transcodificadores e tradutores de informação entre diferentes linguagens e meios (PLAZA, 2003, p. 206).

O discente cujo trabalho apresentamos aqui como exemplo alcançou a inteligibilidade com a proposta, visto que há observação lógica, criatividade e de humor na elaboração do gênero meme. Nesse trabalho, esse gênero foi identificado como uma narrativa multissemiótica, já que foi produzido de forma a articular o enredo do clássico com a linguagem verbal, visual e de humor. Observa-se que: "Há sentido de aprendizado, evolução e representação mental, é o momento de síntese" (PLAZA, 2003, p. 35). É visível na explicação do discente a responsabilidade pela construção do significado. A articulação feita entre a leitura, pensamento e tradução que culminou na síntese do raciocínio. Isso conduziu à associação de elementos constituintes da memória, das formas, dos fragmentos extraídos da história, de qualidades, de análise, de experiências que encaminharam para a criação da narrativa multissemiótica demonstrada. Ele realizou um diálogo entre vertentes diferentes da cultura. Portanto, de acordo com o PCN de Língua Portuguesa (1998), esse estudante pertence ao seleto grupo dos indivíduos que compreendem a leitura.

\section{Considerações Finais}

A intenção da proposta pedagógica era a formação leitora apoiada em outras maneiras de trabalho. A tradução intersemiótica por abarcar diversos meios pode possibilitar multi e interlinguagens, ou seja, ofertar o letramento multissemiótico. Esta técnica revelou-se como instrumento do pensamento lógico que suscita o “equilíbrio entre o sensível e o inteligível" (PLAZA, 2003, p. 209). Torna-se uma opção de reescrita da história, uma forma de síntese de enredos, sentidos e formas.

Dessa maneira, a intenção proposta de pensar outra forma de leitura depois da intermediação da tecnologia é eficaz no que tange à formação leitora. Aliar a escrita, a imagem, a máquina, a leitura de clássico literário e criação de gênero meme como narrativa multissemiótica significa incorporar ao ensino e aprendizagem outras práticas capazes de conduzir o educando à compreensão de conteúdos estabelecidos como barreiras para a efetivação do aprendizado. 
O resultado surgido da análise das traduções intersemióticas demonstrou perspectivas diferenciadas a respeito da estratégia pedagógica. As características individuais e singulares são decisivas no momento de construir o sentido para a leitura. Entretanto, a técnica aplicada aguçou o interesse da maioria, pois a tecnologia promove um efeito inclusivo que entusiasma os indivíduos. Plaza (2003) comenta sobre esta constatação: “[...] a nossa visão, imagem e conhecimento do mundo vêm dados a partir da interação dos campos visuais em dialética com aquilo que sabemos sobre o espaço e o mundo" (PLAZA, 2003, p. 145).

Assim, ao retomar a questão norteadora desse artigo: Quais sentidos podem ser extraídos de narrativas multissemióticas provenientes da triangulação entre diferentes gêneros discursivos advindos de um clássico literário? Os sentidos de construção crítica, de fruição criativa e autoral, de possibilidade de vivenciar suas próprias expectativas, de permissão discente para buscar o aprendizado como melhor lhe convier. Isso mostra como a tecnologia pode ser útil não só fora como dentro da escola.

O diferencial desse trabalho foi a associação entre a leitura e a escrita por meio de imagem. Houve a oportunidade de usar a internet como aliada na construção do saber. 0 projeto piloto possibilitou o desenvolvimento do letramento multissemiótico e a formação leitora do educando.

A experiência apresentou resultado satisfatório. 0 fruto dessa tarefa exibiu pontos positivos em prol da formação leitora. Como também a convicção de que essa sugestão poderá ser aplicada em outras realidades. A operação tradutória permite a exposição do repertório adquirido pela pessoa ao longo dos anos em conjunto com a manifestação da criatividade.

A tecnologia ofereceu uma gama de recursos didáticos capazes de guiar e encaminhar os conteúdos de diversas disciplinas de maneira lúdica e eficiente. A questão está em quando e como usá-las. Ainda se torna urgente o acesso a essas fontes tecnológicas, já que há escolas sem internet, alguns lugares com o serviço precário, como também docentes que são impossibilitados de utilizá-la por variadas razões como financeira, pedagógicas entres outras.

Logo, as informações veiculadas pela mídia é uma face das inúmeras formas que um conteúdo pode possuir. A tradução se converte em uma das verdades que se extrai de uma ideia. Dentro do ato de traduzir estão envolvidas questões de tempo, 
espaço, pensamento, criação, além da máquina, instrumento para concretização do imaginário. 0 tradutor seleciona, fragmenta, recorta, define sentenças conforme seu campo de visão, e é por isso que o produto dessas etapas se transforma em transcrição, transducção ou outra nomeação que o artista queira dar.

Para finalizar, a sugestão apreendida desse estudo é que não se deve usar as técnicas da tradução intersemiótica só para o campo da arte e da poesia. Esse projeto piloto demonstra a possibilidade de aplicá-la em outros campos, como afirma Plaza (2003): “julgamos possível ser pensada a tradução também como forma de iluminar a prática" (PLAZA, 2003, p. 210). É de responsabilidade do educador buscar meios para que aconteça a aprendizagem. Quanto aos recursos, instrumentos, teorias e sugestão existem, basta apenas ir ao encontro deles.

\section{REFERÊNCIAS}

BAKTHIN, Mikhail. Os gêneros do discurso. In: Estética da criação verbal. Tradução: P. Bezerra. São Paulo: Martins Fontes, [1952-1953] 2003a, p. 261-306.

Questões de literatura e de estética. A teoria do romance. São Paulo: Hucitec/UNESP, 1988.

Os gêneros do discurso. In: Estética da criação verbal. Tradução: M.E.G.G. Pereira. São Paulo: Martins Fontes, 1997, p. 277-336.

BRASIL. Parâmetros Curriculares Nacionais: Língua Portuguesa: primeiro e segundo ciclos / Ministério da Educação. Secretaria da Educação Fundamental. 3. Ed. Brasília: A Secretaria, 1998.

COSCARELLI,C. Navegar e ler na rota do aprender. In: COSCARELLI,C. (Org.). Tecnologias para aprender. 1. ed. São Paulo: Parábola Editorial, 2016, p. 61-80.

CHIAPPINI, Ligia. Reinvenção da catedral: língua, literatura, comunicação: novas tecnologias e políticas de ensino. São Paulo: Cortez, 2005.

DAWKINS, Richard. 0 gene Egoísta. São Paulo: Companhia das Letras, 2007.

DIDI-HUBERMAN, Georges. A imagem sobrevivente: história da arte e tempo dos fantasmas segundo Aby Warburg. Trad. Vera Ribeiro. Rio de Janeiro: Contraponto. 2013, p. 11-94.

MACHADO, Arlindo. Máquina e imaginário: 0 desafio das Poéticas Tecnológicas. São Paulo: Editora da Universidade de São Paulo, 1993. 
MELVILLE, Herman. Moby Dyck. Rio de Janeiro.Editora Nova Fronteira. 4⿳a edição, 2012.

PETIT, Michéle. Os jovens e a leitura: uma nova perspectiva. Trad. Celina Olga de Souza. São Paulo: Editora 34, 2a Edição, 2009.

PLAZA. Julio. Tradução intersemiótica. São Paulo. Editora Perspectiva. 1a edição2ª reimpressão, 2003.

RIBEIR0, A. L. Resumo acadêmico: uma tentativa de definição. Revista Científica da Faminas, Muriaé, v. 2, n1, p. 67-77, 2006.

ROJO, R. H. R (0rg) Escol@ conectada: os multiletramentos e as Tics. São Paulo: Parábola, 2013.

Gêneros do discurso e gêneros textuais: questões teóricas e aplicadas. In: MEURER, J.; BONINI, A.; MOTTA-ROTH, D. Gêneros: teorias, métodos, debates. São Paulo: Parábola Editorial, 2005, p. 184-207.

THE NEW LONDON GROUP (GNL). A Pedagogy of Multiliteracies: Designing Social Futures. Harvard Educational Review. Vol. 66. N. 1, 1996.

\section{Biografia dos autores}

Josimar Gonçalvez Ribeiro é professora efetiva do Instituto Federal do Sudeste de Minas Gerais - Campus Rio Pomba - IFSEMG - RP. Graduação em Letras Português/Inglês pela Fundação Educação Dom André Arcoverde (1997), Graduação em Letras - Português/Espanhol pela Universidade Severino Sombra USS (2007), Especialização em Língua Portuguesa pela Fundação Educacional de Além Paraíba (1999), Mestrado em Educação pela Universidade Católica de Petrópolis - UCP (2017), Doutoranda do Programa de Pós-Graduação em Estudos de Linguagens pelo Centro Federal de Educação Tecnológica de Minas Gerais CEFET -MG. Interesses de pesquisa: Práticas Pedagógicas para a formação leitora; Tradução Intersemiótica para fins educacionais; Leitura e Cognição, Narrativas Multissemióticas; Imagens Remixadas. Integra os Grupos de Pesquisa: INFORTEC Núcleo de Pesquisa em Linguagens e Tecnologia do CEFET-MG; Materiais e Recursos Didáticos do CEFET-MG; CIEL - Grupo Interdisciplinar em Estudos de Linguagem do Instituto Federal de São Paulo.

Vicente Aguimar Parreiras é professor do quadro permanente do Centro Federal de Educação Tecnológica de Minas Gerais - CEFET-MG. Graduação em Letras Português/Inglês pelo Centro Universitário Belo Horizonte - UNI-BH (1993), Especialização em Língua Inglesa pela PUC-Minas (1996), Mestrado (2000) e Doutorado (2005) em Letras - Estudos Linguísticos/Linguística Aplicada ao Ensino e Aprendizagem de Línguas Estrangeiras pela Universidade Federal de Minas Gerais - UFMG. Atualmente atua na Educação Profissional e Tecnológica, no Ensino Superior e no Mestrado e doutorado em Estudos de Linguagens do CEFET-MG. Membro titular do Conselho Diretor do CEFET-MG representante dos docentes da 
EPT. Membro suplente no Colegiado do PPG-Estudos de Linguagens. Interesses de pesquisa: Ensino e aprendizagem de Línguas Estrangeiras; Integração das TDIC aos processos educativos; design instrucional; materiais e recursos didáticos; Leitura, Escrita e Cognição; Processamento de Linguagem Natural - PLN. Integra os Grupos de Pesquisa: INFORTEC - Núcleo de Pesquisa em Linguagens e Tecnologia; Letramentos, Processos Discursivos e Tecnologias; Livros, Materiais, Recursos e Novas Tecnologias em Contextos de Ensino e Aprendizagem no CEFET-MG; LALINTEC - Laboratório de Pesquisa em Linguagem e Tecnologia - UFMG. 